\title{
PROTECTION AND DEFENCE OF RAILWAY TRANSPORT AGAINST INTERNATIONAL TERRORISM
}

The authors deal with the threat of international terrorism for the EU and global community and target the attention to infrastructure, critical infrastructure and rail transport. They analyse the EU approach towards the protection of critical infrastructure and point out the core criteria and principles of processing the protective system in separate countries. Moreover they concentrate on the protection of rail transport and possibilities of terrorist attacks. The last part presents danger of radiological terrorism and danger related to transport of radiological material on rails.

Key words: infrastructure, critical infrastructure, traffic infrastructure, rail transport, elements of rail transport, crisis, threat, crisis situation, international terrorism, protection and defence, police activities, police actions, intelligence, analysis and measures.

\section{Introduction}

European integration and world-wide globalisation have a significant impact on the countries in a way that they considerably change social requirements - social order for infrastructure protection, mainly protection and defence of critical infrastructure (CI), transport included - namely rail transport. Besides traditional threats such as disasters, accidents, catastrophes and crimes related to individuals and groups, terrorism represents a new threat. It is an international terrorism, which might have a character of permanent threat for the European and global community [4].

Ongoing terrorist attacks in Europe as well as growing violence in Iraq do confirm the saying that military operations in Muslim countries have only developed a risk of terrorism in the western world. Fails to fight against terrorism by means of wars have paved the way for the fight predominantly by more peaceful means. More and more the people address their governments and ask them to give up wars and instead, try to find the solutions of the reasons of terrorism.

\section{Threat of international terrorism}

Europe has been thinned by an international terrorism of AlQuaeda [1] kind as is the case of train attacks driving the commuters to work and schools in Madrid. 192 people died and about 1600 were injured during the attack of $11^{\text {th }}$ March 2004. As the first step the government accused ETA. Government's approach and socialists' shock were perhaps the most decisive factor that caused the victory of socialists in the election of $14^{\text {th }}$ March 2004 . The new Spanish government pulled its military units back from Iraq and thus fulfilled the election vow nevertheless Al-Quaeda's request as well. The Madrid attacks have intensified the European
Union attempts to combat terrorism. On $15^{\text {th }}$ March 2004 the European Commission issued an Action Paper [11] where contradictory issues and usable tools were drafted. This Paper presents five types of activities which, as proposed by the Commission, the EU shall react to: declaration of solidarity, improved implementation of existing legislative tools being relevant for combating terrorism and adoption of the proposals for measures discussed by the Council, strengthening the fight against terrorism financing, improvement of operational cooperation and coordination, external activity and other tools. On $25^{\text {th }}$ March 2004 the EU leaders adopted Declaration on Combating Terrorism, which acts as a supplement to Action Paper of the EU for the fight against terrorism from the year 2001. One of the objectives of Declaration is to protect the security of international transport. Terrorist attacks aimed at transport systems in Madrid and London in 2005, which resulted in loads of victims and which were caused by Al-Quaeda cannot leave national and international terrorism in Europe unnoticed. Once those attacks for terrorist organizations such as IRA, ETA and FLNC (National Front for the Liberation of Corsica) were performed, a new period comes in the front, the period of searching a new identity because provided you would wish to present yourself as a militant willing to use violence as a tool of enforcing your own political goal, you would face the resistance of the European public poll.

Having witnessed the attacks on the U.S, Spain and Great Britain, the need to protect and defend CI on the national and international level has considerably grown up. That's why the countries and then international organizations themselves have changed their legislation and organizational measures in order to ensure the protection and defence of CI, which is from strategy viewpoint, inevitable for the operation of the state and if lost lives could be endangered that might reason immediate economic and social damage.

* Lubomir Ciganik, Iveta Balasicova

Academy of the Police Force, Bratislava, Slovakia, E-mail: ciganik1@minv.sk 
Critical infrastructure [2] is a strategic element for the state and its failure would lead to a danger for the society as such. The European Union makes huge efforts to prepare Europe for an adequate response to terrorist attacks targeted at elements, buildings and objects of $\mathrm{CI}$ including the protection of rail transport. The current efficiency status of critical infrastructure protection within EU seems to be insufficient; the states are not able to adequately react to changing risk and threats conditions, nor they are able to effectively operate and solve the terrorism-related problems.

\section{Sources of critical infrastructure protection}

In the whole process one may find a quality enhancement in the understanding of security [5]. The principles that are placed in the front are: international or regional cooperation, complexity, comprehensiveness, planning, coordination, legality, subsidiarity and proportionality. Such principles have been even applied by the EU - draft of the Council regulation on identification the European critical infrastructure and assessment of the need to improve its protection.

The draft responds to the EU objectives and is in compliance with the objective stating "Keep and develop the Union as a space of freedom, security and justice, which guarantee free movement of persons and where appropriate measures related to protection of external borders, asylum, migration and prevention and fight against crime have their place" [7]. Moreover it responds to other relevant documents adopted by EU such as "Prevention, readiness and reaction to terrorist attacks" and "Green book on European program on the critical infrastructure protection" (EPCIP).

The Commission is of the opinion that CI does exist in member states and once being violated or damaged, two or more member states might be affected. It is also real that the failure of critical infrastructure in one state may affect the other member state. Thus the Commission states that such critical infrastructures should be identified and marked as European critical infrastructures (ECI) and protective measures should be adopted. Namely, we speak about an integrated approach on EU level that would act as a supplement to national programs for the critical infrastructure protection.

For all member states there must be a common framework, which would ensure coherent and united application of the principles and procedures in dealing with the European critical infrastructure. Common framework should deal first of all with the following issues:

- determine basic notions, - determine sectors where critical infrastructure will be identified, - elaborate methodology of risk and threats analysis, - identify the methods of protection and scope of security measures, - identify range and form of planning and other managing documents, - determine principles for the protection of classified data, - determine scope and method of material and financial provision.
A common framework defined this way should be applied in the national programs either, partly for the protection of European critical infrastructure, but predominantly for other critical infrastructures within a state.

The present requires an optimal, rational and effective system of the protection and defence of CI, transport one including - rail transport, whether we speak about separate areas, sectors, facilities, objects or elements. States and international organizations are expected to create institutional, legislative and organizational conditions for the effective protection and defence.

One of the main tasks within the Slovak security policy is to continuously analyse risks and threats on the national and international level. Risk analysis is a necessary tool how to understand threats in the world of globalisation, not excluding the analysis of security system and the protection of social values. It is obvious that building up isolated state units is not sufficient in this global world; on the contrary it is necessary to build up integrated systems where separate units are able to cooperate and get involved into crisis situations solutions, join one's own attempt according to the scope and character of endanger.

By applying the subsidiarity principle, the EU concentrates on the elements of world-wide significance and leaves other elements of CI system fall under the member states responsibility. Member states contribute to the system by providing information on threats and possible solutions; the system provides risk mapping. All information providers must be assured that information will be processed in an accurate and careful way. We must have at a disposal appropriate legal framework to ensure that classified information is processed properly and protected against unlawful use or publishing. All it falls under the EUROPEAN PROGRAM FOR CRITICAL INFRASTRUCTURE PROTECTION - EPCIP. Its objective is to ensure reasonable and steady security protection, as few failures as possible and fast examined measures.

The level of protection should not be the same for all critical infrastructures, but should be reasoned by the impact, which could cause its failure. Basic criteria for the protection of critical infrastructure are as follows:

- MS governments within their competence shall determine and create the list of critical infrastructures according the EPCIP priorities

- cooperation of industrial enterprises with government in order to provide information and diminish the possibility of incidents that would cause large or long-term breakage of critical infrastructure

- attempt of European Community to create a common approach how to deal with the security of critical infrastructures via the cooperation of all public and private subjects.

Core principles of EPCIP are:

- subsidiarity - protection of critical infrastructure falls under the responsibility of subjects mainly on the national level (MS and owners, providers) 
- supplementary principle - a common framework of EPCIP would supplement already existing measures. Introduced communitaire mechanisms would ensure overall implementation of the program

- confidence - information of critical infrastructure protection would be kept in confidential environment and protected against misuse

- cooperation of subjects involved - all subjects involved, including MS are given a certain task in CI protection. MS bodies would be appointed the leading and coordinating status in the development and implementation of approaches for CI protection in a given territory. Owners, providers and users would be actively involved on the national and EU level

- proportionality - protective strategies and measures should be proportional to a certain danger. They should concentrate on the most risky areas

- indivisibility of security - strengthening of $\mathrm{CI}$ in the EU could be reached by the implementation of EPCIP, i.e. common objectives, methods etc. which would enable the exchange of the best practices and control mechanisms.

By its resolution no. 967 of $7^{\text {th }}$ December 2005, the Slovak government adopted "Plan for the Security Council of SR for the year 2006" and put vice-chairman of the Slovak government and Economy Minister under an obligation to submit the "Conception of critical infrastructure in SR and the protection and defence methods", which was performed. By its resolution no. 120 of $14^{\text {th }}$ February 2007 the government adopted the draft of submitted conception and at the same time requested to elaborate the National program for the protection and defence of CI in SR and submit the bill on critical infrastructure. Submitted conception creates a sufficient space for complex elaboration of $\mathrm{CI}$ in SR in connection to EU standard.

\section{Subjects of protection and sources of critical infrastructure protection}

Subjects [6] involved in the protection and defence of rail transport are:

- international organizations, international partners

EU - common security policy, common security measures (recommendations), common legal protection of $\mathrm{CI}$

COLPOFER, RAILPOL - cooperation

- government, public administration

legislative, executive and judicial power, adoption of legal framework for the protection and defence of rail transport, division of competences into public authorities, SIS (Slovak Intelligence Service), police, railway police and armed forces competences, etc.

- territorial units

integrated rescue system, evacuative plan, civilian emergency planning

- state and private economic operators

Railways of SR (Železničná spoločnost’, a.s.)
Subjects involved in the solution of rail threats concentrate on the following areas:

- risk and threats monitoring and analysis, development tendencies

- strengthening the protection of objects and facilities

- defence of separate objects and facilities against possible terrorist attacks

- civil protection tasks, alleviation of consequences, health service, vet service, consolidation of area of activities or state region

- emergency operation of rail transport, emergency transport of citizens and loads, emergency routes

- recovery of functional and effective status of rail transport.

Police competences result from the legal framework, which also determines the scope and contents of involvement. According to the valid legislation and international agreements binding for the Slovak Republic we may state that the police services (armed security forces and armed forces) concentrate on the competences and tasks resulting for each state in the area of protection and defence. Railway police have at their disposal power and tools to accomplish all the tasks related to prevention, lowering the risk of being endangered, warding off the attack, alleviation of consequences and substitute operation of rail transport.

In order to perform the job of the Railway police effectively, the risk analysis and assessment should give a response to the basic questions such as:

- Which elements of rail transport, facilities, premises and objects might be endangered?

- What are possible targets of terrorist attacks (destruction, contamination etc.)?

- Where are these targets situated?

- How might these targets be reached (taking hostages, kidnapping, etc.)?

- What are the weak points of rail transport protection?

- Who are potential terrorists?

- What is the level of training of persons in charge of the protection?

- How are technical tools applied?

- What is the cooperation with the police, rescue and emergency services (armed security forces, armed forces)?

- How is watch service applied for citizens (warning system) and public administration?

While drafting the plan of the protection and defence we follow the conclusions of the risk analysis and assessment as well as determine the terrorist goals. The attacks may be targeted at elements, facilities and objects of the rail transport such as:

a) trafo-stations and switch-control rooms, high tension nets, energy supervisor, compress stations

b) cars, stocks with chemical materials - burning, explosive, poisoning (ammonia) etc.

c) cars, stocks with radioactive material, etc.

d) rail crossings, bridges, tunnels, etc.

e) trains, railway stations

f) destruction, violation of the transport (e.g. violate the direction)

g) connecting systems including communication systems and technologies etc. 
Nuclear (radiological) terrorism may be of the following forms: the use of stolen or otherwise obtained ready-to-use nuclear gun, the attack by the use of nuclear explosive device made from stolen cut material, the use of device in order to disperse explosives of highly radioactive (radiological) material (so-called dirty bomb) or the attack or sabotage against nuclear (radiological) device [3] or transport, where radioactive dispersion is possible.

Transport of radioactive materials is in the process of development due to their increasing usage. There are approximately 1.5 millions deliveries in the EU within one year. Such a transport joint with the production of electricity represents, in fact, a small percentage out of overall number of such deliveries.

At this point, regulations and procedures valid in individual states come to the front. Nowadays, the internal regulations of the states are more or less the same, since they are based on international requirements (ADR - The European Agreement concerning the International Carriage of Dangerous Goods by Road, RID the International Carriage of Dangerous Goods by Rail, ICAO International Civil Aviation Organization, IMDG - The International Maritime Dangerous Goods). It is more than important to carefully apply such requirements.

Transport of radioactive material in Slovakia is set by Act no.94/2007 Coll. from $7^{\text {th }}$ February which is a supplement of Act no. 541/2004 Coll. on peaceful usage of nuclear energy (nuclear act) as amended and which changes the Act no. 238/2006 Coll. (act on nuclear fond). Besides others, the Act determines the competence of the Bureau of Nuclear Supervision in the Slovak Republic in the field of transport and loading of nuclear material, radioactive waste and burnt nuclear fuel, physical protection of the nuclear material transport and emergency planning. The act takes into account the requirements issued by International Agency for Nuclear Energy.

Besides administration documentation necessary for citizens' security, the Bureau approves, first of all, the means of transport usable for no longer than a five-year period. Valid are the regulations of the above mentioned act no. 94/2007Coll. as well as the provisions of the Bureau of Nuclear Supervision in the Slovak Republic which determines the details on requirements for the transport of radioactive materials (decree no.57/2006 Coll.). This decree regulates the procedures and methods of road, water, and air transport of radioactive materials.

When terrorist attack (using biological, chemical and radiological material) [5] is in question we must respect the fact that the society cannot be fully ready for any circumstances. Furthermore we must take into account the fact that a possible biological, chemical and radiological attack always brings its casualties. However, we must create, build and prepare a system, which would considerably reduce the number of these casualties. First persons who will respond to such attacks are members of Fire and Rescue Service, teams in charge of loading dangerous material, members of Railway Police and health rescue services and medical person- nel since they will provide a first aid kit, maintain public order, search and prosecute offenders. Thus the requirements for training of such units are tough in order to improve their experience and skills.

Security authorities are empowered to eliminate the risk on maximum. One of the key players is the police and its coordination with other security services, mainly with Slovak Intelligence Service whose primary task is to obtain and analyse the information on organized terrorism. Railway police and the police itself are the core elements of the security system in the state and such a system must be comprised even in the protection of rail transport against terrorist threats. Nowadays, there is a need to improve the efficiency of the protective measures in the area of prevention, criminal intelligence, investigation and special task services, their use in our environment by relevant means, appropriate methodology of service activities within the cooperation and concurrence.

\section{Conclusion}

Plans in crisis situations must follow the principles and conditions of the fight against terrorism and respect the conditions and specifics of a certain area, territory and object. The plans are becoming practical measures and instructions in case the transport has been violated and basis for tactics of how to face them effectively and actively. The crisis plans may have different forms, however we may divide them into three categories, each of them has its own emergency measures. The categories are: measures against terrorist act, measures in the course of terrorist act and measures after the terrorist act is over.

To prevent and avoid the rail transport from being endangered it is necessary to have at a disposal certain measures, sufficient and effective forces and tools of the railway police. The goal of these preventive measures - actions is to discourage offenders and to pull them away from the attractive targets. If, nevertheless, the attack is performed, the measures enable to use those forces and tools in the territory in order to respond to the attack, search, isolate and apprehend the offenders.

One of the most effective measures is to perform security measures before the terrorist attack takes place [1] - in a certain territory. Such measures may be realized as a kind of the police preventive activities. Their scope, intensity and period will result from the level of danger (confirmed by intelligence activities, etc.) but, however still there is a space for political and economy decisions.

Protective and defensive police actions, which target at the protection and defence of the rail transport might get a global (international), regional (over-national) and local (national) character. Most frequently the preventive police actions will focus on the immediately endangered territory of rail routes, protection of objects - railway stations, stocks, cars and rail telecommunication. 


\section{COMMNICOIIIONS}

\section{References:}

[1] CIGANIK, L., JASSOVA, E.: Terrorism (in Slovak), Ustav politickych vied Slovenskej akademie vied, VEDA, Bratislava, 2006, ISBN 80-224-0892-1.

[2] HOFREITER, L.: Protection of critical infrastructure (in Slovak), 9. vedecka konferencia s medzinarodnou ucastou, 1. a 2. cast, ZU Zilina, 2004, ISBN 80-8070-272-1.

[3] KIS, M., HRABOVSKA, D.: Developmental models of crisis situation and application of measures related to economic mobilization in order to eliminate negative consequences of crisis situation (in Slovak), 9. vedecka konferencia s medzinarodnou ucastou, 1. a 2. cast, ZU Zilina, 2004, ISBN 80-8070-272-1.

[4] KULICH, M. et.al: Terrorism (in Slovak), Terorizmus destabilizujuci fenomen sucasnosti a boj proti nemu, Bratislava: MO SR, 2002.

[5] PAWERA, R.: New insight into European Union security (in Slovak), Policajna teoria a prax, Akademie PZ, Bratislava, 3/2004.

[6] PRUZINSKY, M.: Protection of critical infrastructures (in Slovak), 9. vedecka konferencia s medzinarodnou ucastou, 1. a 2. cast, ZU Zilina, 2004, ISBN 80-8070-272-1.

[7] SIMAK, L.: Security system of SR after EU entry (in Slovak), Ochrana osob a majetku, Kosice, 2004, ISBN 80-969148-7-1.

[8] Conception of internal security of the Slovak Republic.

[9] National action plan of the fight against terrorism of the Slovak Republic.

[10] Constitutional law and other legislative regulations stated.

[11] European Commission action paper in response to the terrorist attacks on Madrid. 